\title{
THE IMPACT OF ACADEMIC CAPITALISM ON THE FORMATION OF INNOVATION POLICIES IN HIGHER EDUCATION AND SCIENCE
}

\author{
Oleksandr Romanovskyi ${ }^{1}$, Yuliia Romanovska ${ }^{2}$, Oleksandra Romanovska ${ }^{3}$
}

\begin{abstract}
Innovation policy in the field of higher education and science is one of the main components of the state socio-economic policy of social development and is aimed at creating favorable conditions for the market launch of new ideas created in this sphere. The purpose of the study is to analyze the decisive influence of academic capitalism on the formation of innovation policy in higher education and science, contributing to the creation of an innovative environment for transformational change in this sphere. The methodology of the research is based on an objective standardized approach to the analysis of factual data on the development and implementation of innovation policy in higher education systems and leading universities of the world, the latest published results of experiments, materials of scientific literature on innovation policy and innovation management. Research results. The main directions of innovation policy of entrepreneurial university and innovation relations in the sphere of higher education and science are investigated. It is shown that innovative transformations in the sphere of higher education and science, as a rule, take place within the framework of the innovative policy determined by the leaders of this sphere. It is noted that innovation policy in higher education is a link between the policy of research and scientific (scientific and technical) activities, search and dissemination of knowledge, education and training of qualified specialists in the field of technological development, industrial policy and environmental policy. The authors studied the following: the types of activities promoted by innovation in higher education and innovative environment of this activity; the main directions and main components of innovative policy of entrepreneurial university; innovative relations in higher education and science; innovative environment; the importance of having the necessary competencies, their formation and development; internal and external sources of competencies for universities, etc. Practical implications. The authors suggest that innovation policy in higher education is a link between the policy of research and scientific (scientific and technical) activities; search and dissemination of knowledge; education and training of qualified specialists - on the one hand, and technological development; industrial policy and environmental policy - on the other. This can be used in the creation of the theory and practice of innovation policy development in higher education. The article as a whole is devoted to the further development of the theoretical foundations of higher education innovatics.
\end{abstract}

Key words: academic capitalism; higher education innovatics; innovative policy; innovative environment; management of innovation activities.

JEL Classification: A23, 121, 125, O31, O32

\section{Introduction}

Numerous studies and scholarly literature provide useful information about the positive impact of academic capitalism on the socio-economic and sociohumanitarian spheres of human activity. Analyzing the impact of academic capitalism on innovative transformational changes in higher education and science, on the development of academic or university entrepreneurship, and on the further promotion of innovation in higher education and science, it is

\footnotetext{
Corresponding author:

${ }^{1}$ Private Higher Educational Establishment-Institute "Ukrainian-American Concordia University", Ukraine.

E-mail: oleksandr.romanovskyi@uacu.edu.ua

ORCID: https://orcid.org/0000-0002-3618-2999

${ }^{2}$ National Pedagogical Dragomanov University, Ukraine.

E-mail: yuliia.romanovska@uacu.edu.ua

ORCID: https://orcid.org/0000-0002-0207-3348

${ }^{3}$ Private Higher Educational Establishment-Institute "Ukrainian-American Concordia University", Ukraine.

E-mail: internship_wiuu@hotmail.com

ORCID: https://orcid.org/0000-0003-3614-544X
} 
necessary to investigate the impact of innovation policy on these processes.

The authors devoted this article to the study of the main directions of innovation policy of entrepreneurial university and innovation relations in the sphere of higher education and science. The article considers innovative transformations in the sphere of higher education and science, which, as a rule, take place within the innovation policy determined by the leaders of this sphere.

Innovation policy in higher education is studied, which acts as a link between the policy of research and scientific (scientific and technical) activities, search and dissemination of knowledge, education, training of qualified specialists in the development of technology, industrial policy, environmental policy.

The object of the study is the activity promoted by innovation in higher education and innovative environment of this activity; the main directions and main components of the innovation policy of the University of Entrepreneurship; innovative relations in higher education and science, as well as innovative environment. The important tasks of innovation policy are determined by the availability of necessary competences, their formation and development. Internal and external sources of competencies for universities, etc. are considered.

Consider some publications that contain the fundamentals of the theory of academic capitalism, theory of innovation, innovation management, academic or university entrepreneurship, innovation activity, innovation policy, innovation environment the main factors of innovation management in higher education and innovation transformation of science. These works formed the basis of the theory and practice of the interdisciplinary direction of higher education innovatics (Romanovskyi \& Romanovska, 2020).

According to S. Slaughter and L. Leslie, the essence of "academic capitalism" is the transformation of research and teaching into a kind of entrepreneurship: the implementation of research projects depends directly on receiving cash subsidies from individual corporations (Slaughter \& Leslie, 1997).

"Academic capitalism" sets new directions for the development of modern higher education and manifests itself at three levels: institutional, departmental, and individual. Academic capitalism at the institutional level is realized against the background of changes in the financing of higher education institutions, the reduction of state funding and the need to find sources of additional funds. The study of academic capitalism at the department level is of interest because it is where a variety of activities take place and staff members adapt to new values. At the individual level, within academic capitalism, there is a redefinition of the distribution of time between the core activities of faculty: teaching, research, service (Leslie, Oaxaca \& Rhoades, 2001).

In its essence, the environment of academic capitalism, which has embraced the sphere of higher education and science (as well as all other social, social and humanitarian spheres of human activity) by market and market-like relations, is also a new phenomenon in the general system of capitalism. It was in the environment of academic capitalism that the powerful innovative development of both the socialhumanitarian and industrial spheres of human activity began. The acceleration of innovation gave rise to the digital revolution and has become the objective reality of today's globalized world.

A complete description of innovation processes was made by J. Schumpeter: he analyzed "new combinations" of changes in the development of economic systems. He added a definition of innovation as "new combinations" of new or existing knowledge, resources, equipment, and so on (Schumpeter, 1934, p. 65). Also J. Schumpeter and G. Mensch introduced the term "innovation," which was defined as the translation of a scientific discovery into a new technology or product (Schumpeter, 1976; Mensch, 1979).

A number of works are devoted to the definition of the concept of "innovation" (for example: Baregheh, Rowley, \& Sambrook, 2009; Edison, Ali, \& Torkar, 2014; Rogers, 2003; Drucker, 2002), etc. The theoretical foundations of innovation, innovative development, and innovation management, include the 2006-2016 global study of innovation management in the book (The Quest for Innovation, 2006), in the article (Chen, Viardot, \& Brem, 2019), and in the works of L. Bouwer (Bouwer, 2015; 2017).

In his comprehensive book F. Damanpour synthesizes the research of the last 50 years in the field of innovation, reviewing the basic elements of innovation and providing an interconnected perspective on innovation in organizations. The author provides an overview of key concepts, terms and theory, explores processes of generation and adoption of technological and non-technological innovations, examines innovation activities and internal mechanisms and procedures in organizations (Damanpour, 2020).

This research is based on the following conceptual foundations of innovative development of higher education:

- H. Etzkowitz's concept of innovative development of society by the triple helix model (Etzkowitz, 2003; 2008; 2019; Viale \& Etzkowitz, 2010; Dzisah \& Etzkowitz, 2012; Cadorin et al., 2019), which is successfully used in many developed countries (USA, UK, Canada, Australia, Japan, Germany, Sweden and many other countries of the EU) and in the developing world (China, Russia, Brazil, some other South American countries, etc.); 
- B. Clark's concept of transforming conventional universities into innovative universities focused on internal entrepreneurial activity (business universities) (Clark, 1998; 2000; 2004), which has been confirmed in the higher education systems of many countries of different continents (North and South America, the USA, Western Europe, Japan, Africa).

- The Innovation Policy Platform (IPP), developed by the World Bank Group and the Organization for Economic Cooperation and Development, is an interactive web-based space that provides easy access to knowledge, learning resources, indicators, and communities for innovation policy design, implementation, and evaluation. The platform helps users learn how innovation systems work, identify best practices in different countries, conduct statistical comparative analysis, and develop and implement effective policy solutions. More broadly, it facilitates knowledge sharing and cooperation between countries and regions (The Innovation Policy Platform, 2013).

For more than 50 years, the sphere of higher education and science has been subject to various innovative changes, the direction of which depends on the goals set by innovators. Since practically all areas of social, economic and social-humanitarian activity of mankind are connected with the sphere of higher education and science, it is reasonable to investigate, identify and group innovations according to the spheres of application and the tasks set before them.

\section{Analysis of recent studies and publications}

Among recent publications devoted to innovation in higher education, the following works seem interesting.

In "Innovation in higher education; will there be a role for 'the academe/university' in 2025?" Eddie Blass and Peter Hayward present five scenarios for the future of higher education based on factors such as funding, ownership and use of "research", ensuring good "teaching," and the potential missing link: developing social innovation. The authors emphasize that by refocusing on fostering social innovation, the university can find a new means of adding value to society that will sustain it after 2025 (Blass, \& Hayward, 2014).

In his article, Dustin Swanger examines the current state of higher education and the pressures facing colleges. He also explores innovation and some of the challenges facing innovation in higher education, as well as some successes. The article recommends some changes that can be implemented on any campus to improve outcomes and efficiency (Swanger, 2016).

P. Serdyukov's article is devoted to the problem of innovation in American higher education. Analyzing the publications of American specialists in the field of higher education and innovation, studying the real situation with the use of innovation in higher education institutions, he notes the following (Serdyukov, 2017).
Unbundling is the process by which products previously sold together are separated into their component parts. In (McCowan, 2017), the author argues that there has been a dynamic separation of teaching and research in higher education. This dynamic has been primarily financially motivated and driven by the for-profit sector, but has also had a pedagogical motivation in the form of an emphasis on personalization and employability. This article presents a theoretical analysis of this trend and proposes new conceptual tools with which to chart the regulatory implications.

The article (Jakovljevic, 2018) deals with institutional innovation and some models of innovation in higher education. The author concludes that modern research on innovation informs us about the models and nature of innovation and their main facets: a) TAR model; b) stakeholder model; c) structural model; d) structured governance models and e) triple helix and quadruple helix innovation models.

In the book (Branch, Hørsted, \& Nygaard, 2018) presents key examples of innovative teaching and learning practices in higher education. The book is truly international, with contributions from Australia, England, Denmark, Hong Kong, Italy, Qatar, Scotland, South Africa, Tasmania, Vietnam, and the United States. Although the educational settings in these countries are very different, there are striking similarities in approaches to innovative teaching and learning.

The following works (Jessop, 2018; Somers et al., 2018; Münch, 2020) are devoted to a critical study of the problems of academic capitalism.

The OECD's Mission-Oriented Innovation Policies (MOIP) is an online toolkit that provides an easyto-follow guide to help policymakers develop and implement mission-oriented innovation policies. "With the support of policymakers and through partnerships with individual institutions, the toolkit is intended to be a reference platform for all those who develop, implement or research and advise on mission-driven innovation policies. Faced with growing societal challenges of unprecedented scale and scope, several governments are experimenting with a new policy approach of pooling effort, resources, and knowledge across disciplinary, sectoral, and political blocs to collectively address clear, bold, and inspiring goals. Building on the lessons learned from these early experiments, this online policy toolkit is designed to provide policymakers with analytical knowledge and practical information on designing, managing, and implementing MOIP initiatives" (Mission-Oriented Innovation policies, 2020).

The author of the following paper, S. Otten concludes that it is generally agreed that innovative and inclusive approaches to policy development include the 
following methodologies, such as: a) collaborative design with stakeholders; b) user/customer-centered design - an iterative design process in which users and their needs are central to each stage; c) Design thinking - a methodology of discovery/design/ prototyping/testing/repetition; d) Understanding the customer journey from start to finish, including pain points; e) public interaction - open communication with citizens and stakeholders; f) seeking and considering different opinions and experiences.

These points are closely related to the others, and there is quite a bit of overlap. They have quite a bit to do with maintaining the role of the user in the process, stakeholder collaboration, and community engagement (Otten, 2018). The author analyzes the experience of innovation policy development in countries such as Australia, Denmark, Mexico, New Zealand, Singapore and the United Kingdom.

\section{Purpose of the article}

The aim of the study is to analyze the decisive influence of academic capitalism on the formation of innovation policy in higher education and science, contributing to the creation of an innovative environment for transformational change in this sphere.

This study is also a further development of the theory and practice of university innovation, defining the tasks, directions and features of innovative transformations in higher education and science. An important issue of the study is the effective organization of management in the field of innovation transformation, innovation policy and innovation relations in the subjects of higher education and science - universities and research institutes.

\section{Research methods and methodology}

The authors used the following research methods: - dialectical approach to analyzing and understanding the content and features of innovative development of higher education under the influence of market relations of academic capitalism and university entrepreneurship;

- analysis of innovative transformations as economic categories in the system of socio-economic relations and interrelations of the integral economic system of the modern knowledge society;

- methods of abstraction, system-structural and information-theoretical approaches are used to study the conditions for the formation of new innovative forms of university entrepreneurship, the features and essence of entrepreneurial activity of the university; - a critical study of the impact of innovation transformation and academic entrepreneurship on the financial sustainability of higher education institutions;
- methods of analysis and synthesis are used to study various innovative approaches and technologies in higher education and form a complete picture of the complex innovative activities of subjects, objects and the higher education system as a whole.

The methodology of the research is based on an objective standardized approach to the analysis of factual data on the development and implementation of innovation policy in higher education systems and leading universities of the world, the latest published results of experiments, materials of scientific literature on innovation policy and innovation management.

The research methodology includes:

- methods of empirical research of innovations in higher education, (including observation, experiment, comparison, measurement and comparison);

- statistical methods of scientific description and study of various innovative phenomena in the system of higher education that allow quantitative (numerical) expression;

- critical examination and awareness of the concept of innovation in higher education;

- analysis of literary sources, including electronic and computer-based tools; comparison and verification of the feasibility or necessity of implementing various types of innovation, analysis of their effectiveness and the possibility of spreading and implementation on objects and subjects of higher education system; forecasting ways of forming new innovation policy, innovative approaches, methods and technologies; integration of research results and the formation of scientific-theoretical, methodological and practical provisions of the new direction - innovation of higher education.

\section{Presentation of the main research material}

Innovatics of higher education is a branch of knowledge aimed at the study, creation of explanation and effective implementation of innovations in higher education and science. The authors will consider the main results of the study of innovation policy in higher education and science and directions of its implementation.

Further development of the sphere of higher education and science directly depends on the quality of innovation policy and intensity of innovation in this area. The main role is played by the human factor, which creates an innovative environment and uses the necessary innovative technologies, methods, techniques and approaches.

Analyzing the publications on this topic, the article (Cai \& Qiongqiong, 2020) addresses some issues of innovation policy of higher education and university leaders in the process of building innovation ecosystems as an environment for the development of higher education and science. 
The work (Borrás \& Edquist, 2015) on how governments and leaders pay (and should pay) attention to building competencies (including education, training, skills, and practical experience) when designing and implementing innovation policies is significant. The article proposes a typology of internal and external, individual and organizational sources of innovation-related competencies. This is necessary to examine the most common initiatives taken by governments in this direction. The paper identifies three common weaknesses and imbalances in innovation systems in terms of education, training, and skills: a) insufficient levels of competencies in the system; b) the time lag between the short-term needs of firms for specific competencies; c) the long time required to develop them, and the imbalance between internal and external sources of competencies in firms. The authors developed a set of general criteria for restructuring policy instruments to address these tensions and imbalances.

In (Tierney \& Lanford, 2016), the authors believe that higher education in the $21^{\text {st }}$ century faces global forces that require innovative research, innovative pedagogy, and innovative organizational structures. A theoretical understanding of innovation is essential to the continued development of higher education and science. The authors outline such a conceptual framework based on the innovative literature in various academic disciplines. Thus, there are four inevitable trends in higher education that can lead to innovative responses. Working definitions of creativity, innovation, and entrepreneurship are given by clarifying a number of terms related to innovation. The concepts of sustained and disruptive innovation are discussed. This shows that change and innovation have been a constant feature of higher education since its inception. Three aspects of innovation are considered - diversity, intrinsic motivation, and autonomy. These aspects have a positive impact on the ability of people in higher education to innovate. Three complementary concepts - time, efficiency, and trust - are then examined, which are important for scrutinizing innovation in an institutional setting.

Further, turning to the United States, there is evidence that the American system of higher education is considered an important factor in national economic, scientific, and social progress. More than four thousand public and private institutions of higher education, awarding degrees and professional qualifications, significantly improve the quality of their educational and scientific activities, using innovative technologies, methods, techniques, approaches and solutions.

Due to the increasing complexity of production processes in all spheres of human activity, the demand for higher, vocational and specialized technical education is constantly growing. According to experts published before the COVID-19 pandemic, the number of full-time students is expected to reach more than 23 million by 2025 (Brewer \& Shirley, 2017).

Over the past 20 years, growth in college enrollment has come mainly from non-traditional students (i.e., those who did not attend college right out of high school and those who do not attend college full-time), who now make up about 40 percent of all students.

The serious problem of expanding access comes after decades of skyrocketing tuition fees. The reasons for these increases range from unprecedented competition for outstanding faculty and talented students to a bloated administrative apparatus, changing students' tastes and status from diligent consumers of knowledge to market consumers demanding more services, and declining teaching loads of full-time faculty. Despite rising student tuition revenues, many colleges and universities are under severe financial pressure as operating costs rise faster and government support for public institutions declines. In this sector, innovation is critical to meet U.S. needs in the coming years.

Innovation in U.S. higher education can be defined as the introduction of new methods and practices to improve production efficiency (Brewer \& Tierney, 2011).

For most teaching and learning-oriented sectors, this means recruiting students and providing them with opportunities to earn a degree (ultimately, in the hope of producing productive and successful citizens) that result from some process of learning combined with a range of operational support services. Innovation is possible with both instructional and operational support and involves creativity, risk-taking, and experimentation at the institutional level.

Innovation by an institution of higher education or other organization depends on a number of factors, including the availability of new technological capabilities and the market and social context in which they operate. Labor-intensive industries are innovating using a number of approaches, including a) the use of information technology; b) different work strategies, such as greater job differentiation, use of contingent workers and creative compensation schemes; c) re-engineering key processes, such as through subcontracting; and d) a focus on the core mission and separation of supporting activities.

Federal policy plays a crucial role in driving innovation in higher education through levels of funding and regulation, as well as a broader regulatory environment that affects learning and operations.

The authors made recommendations in three main areas: redesigning student financial aid, creating regulatory frameworks that facilitate institutional experimentation, and creating new designs for broader implementation (Brewer \& Shirley, 2017).

Analyzing data from many scientific sources and summarizing the results of their own research, the authors propose to consider the activities promoted 
by higher education innovatics (Romanovskyi, Romanovska \& Romanovska, 2021) and the innovative environment of these activities (Figure 1).

All of the activities promoted by higher education innovatics take place in such an innovative environment:

One of the tools of innovation management in the sphere of higher education and science is the innovation policy (innovation policy). As it is known, the innovation policy is the state policy directed on control and maintenance of balance between the rights of owners of the information and necessity of innovations and technical progress. On the other hand, innovation policy is a link between the policy of research and technological development and industrial policy. It aims to create favorable conditions for bringing ideas to market.

The authors suggest that innovation policy in higher education is a link between the policies of a) research and scientific (scientific and technical) activities; b) search and dissemination of knowledge; c) education and training of qualified specialists - on the one hand, and d) technological development; e) industrial policy and f) environmental policy - on the other.

In general, innovation policy in the sphere of higher education is one of the main components of the state socio-economic policy of society development and is aimed at creating favorable conditions for the introduction of new ideas created in this sphere to the market.

Innovation systems are divided into national innovation systems, regional innovation systems, local innovation systems, technological innovation systems and sectoral innovation systems. At that, the following levels can be considered: state; branch (sphere of higher education and science); regional or local; subjects of branch subordination (universities, colleges, various educational institutions or scientific institutions, other organizations of higher education and science system, etc.).
O. Granstrand and M. Holgersson define the innovation system as "a set of components and causal relationships that influence the creation and use of innovation and innovation activities" (Granstrand \& Holgersson, 2020).

When considering a university or research institute, it is necessary to distinguish between external and internal innovation policies.

External innovation policy is a joint, team-coordinated line of behavior of a university or research institute in the market of educational and scientific services, defining priority innovative projects and leading to an increase in the level of development of the university or research institute.

Internal innovative policy is a regulation of behavior of the personnel directed on innovative type of development of university (research institute). The essence of personnel behavior is determined by relations that develop between employees in the innovative sphere of university or research institute activity. In general, the innovation policy of higher education institution or research institute is a guide to the choice of priority areas of the innovation process, development and implementation of innovative plans and projects, formation of the necessary relations between employees in the university (research institute). By its type the innovation policy of higher education institution or research institute can be different: narrowing (reduction); stable functioning; growth (expansion).

The policy of contraction (reduction), steady functioning or growth (expansion) is based on an analysis of the goals of the university or research institute, which are defined as the specific end state (final position) of the university or research institute, or the desired result.

In determining the purpose decrease (reduction) of the final state (position) of the university or research

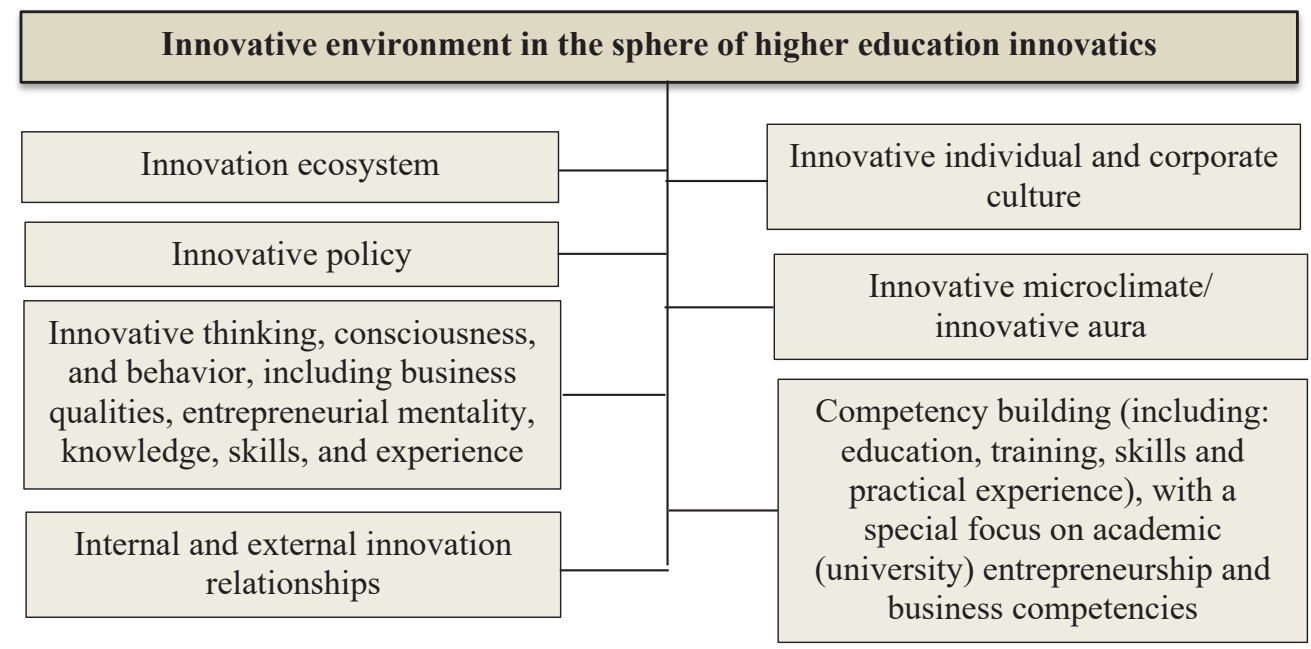

Figure 1. Innovative environment in the sphere of higher education innovatics 
institute is seen in the maintenance, preservation of the production of scientific and educational services, the share of the mastered market of such services, wages and number of employees or in a gradual slowdown in the growth of scientific and educational services, hoping for the opportunity of promotion in the future. The goals of contraction (reduction) are chosen by universities and research institutes working under unfavorable conditions. Investments in innovative projects in this case are either absent or incidental. This is the policy of survival.

Innovative policy of stable functioning provides for comprehensive improvement and enhancement of the quality of educational and scientific activities through the introduction of innovative methods and technologies. At the same time there are no plans to increase or decrease the volume of statutory activities. Growth (expansion) goals imply a positive trend, the difference between them depends on their content, and they can be aimed at:

- achieving a high level of educational, scientific, methodological and technological development, which is manifested in the state of the implemented educational and scientific processes and learning technologies - in the degree of their novelty, quality, efficiency, productivity, progressiveness;

- achieving a high level of economic development of the university or research institute, which is manifested in an increase in the competitiveness of educational and scientific products and services, increasing market share, expanding volumes, improving financial results and financial condition;

- achieving a high level of social development of the university or research institute, which is manifested in the socialization of the results of activities and increasing the role of the individual - the humanization of the management process.

Investments in innovations in the framework of growth policy are regular and have a clear direction, which characterizes the innovation policy. Innovative growth policy is characterized by external (socialization of activity results) and internal (humanization of management process) social orientation.

The policy of innovative growth can be extensive or intensive, risky or moderate, and allow the use of alternative sources of funding and investment.

The main principles of the external innovation policy of the sphere of higher education and science and its structural subdivisions (universities and research institutes) are:

- the unity of scientific and educational processes, administrative and managerial activities and their focus on the economic, social and spiritual development of society;

- optimal combination of state regulation and budgetary financial support with self-government and means of self-sufficiency;
- formation of innovative projects in priority areas of research, defined by state and regional innovation and scientific-technical policy;

- support of leading scientists, scientific teams, research and scientific-pedagogical schools, capable of providing the advanced level of education and scientific research, development of scientific and technical creativity of young people;

- conducting a full cycle of research and development, ending with the introduction of ready-made services and products, the formation of start-ups (spin-off and spin-out);

- support of entrepreneurial activity in the scientific sphere, broad commercialization of $\mathrm{R} \& \mathrm{D}$ results;

- Internationalization of education, followed by the integration of science and education into the international community;

- formation of network structures in the organization of innovative and scientific and technical activities; formation of the world base of scientific knowledge.

Internal innovation policy should be formed and implemented on the basis of the following principles:

- continuous development of the innovative capacity of the university or research institute required to implement innovations;

- comprehensive implementation of innovations, in which all types of innovations are closely interrelated and mutually contribute to each other;

- creation of a structural unit responsible for the formation and implementation of innovation policy and strategy;

- mobilization of personnel, maximum use of financial, material and intellectual resources to implement innovations;

- material, moral and social encouragement of innovation activity;

- risk accounting and assessment.

Innovation policy of entrepreneurial university, as a tool for managing its development, is a decisive factor of innovation activity, one of the important elements of the innovation process in the university, research institutes, etc. This policy should contribute to the disclosure of innovative potential, the creation of innovative-active, effective behavior of the personnel.

The innovation policy of entrepreneurial university should take into account the peculiarities of the activity of an educational institution focused on academic entrepreneurship. The main components of the innovation policy of entrepreneurial university are:

\section{Environment:}

- external-favorable, neutral, unfavorable: regional (municipal) level; national level; international level; - internal.

2. The goal of university development:

- narrowing (decreasing);

- growth (expansion): extensive; intensive. 
3. The attitude to risk:

- risky;

- moderate (moderate).

4. Field of activity:

- educational;

- scientific (scientific and technical);

- cultural and educational activities;

- administrative and managerial support;

- financial;

- academic and entrepreneurial;

- related business (provision of various paid services);

- economic, commercial, auxiliary, and other types of university activities;

- sports, leisure, everyday life, extracurricular activities of the university.

5. The nature of innovation selection:

- selective;

- indicative;

- comprehensive.

6. Sources of funding for universities:

- budget;

- extra-budgetary;

- your own;

- multi-channel system for finding, attracting and accumulating funds

7. The method of forming the innovation policy of universities:

- traditional;

- intuitive;

- scientifically based.

8. The nature of the implementation of the innovation policy of universities:

- stable;

- unstable.

9. The degree of entrepreneurship implementation:

- low (medium);

- high.

10. Expected results of the implementation of the innovation policy of universities:

- innovative development of higher education institutions;

- innovative development of the region;

- local, regional and national economic growth.

External and internal policy of universities is under stood in the same way as for enterprises (organizations). The peculiarity of modern external innovation policy of the university is the introduction of the best foreign experience of the world's leading universities in international education, internationalization of higher education, the introduction of distance learning, partnerships with foreign universities and exchange them with students and faculty. The same applies to exchanges with entrepreneurial universities.

Extensive innovation policy is a policy of change in the direction of quantitative development of certain characteristics of universities that are amenable to innovation.
Intensive innovation policy is a policy of change in the direction of qualitative improvement of relevant characteristics.

In terms of risk, universities are characterized by a moderate innovation policy.

Given the specifics of universities, risk taking can only take place in scientific activities (research and implementation of the results of the latest scientific and technological developments and technologies). But the university needs to develop a risk management program. Among risk management methods, preference should be given to risk insurance and the distribution of responsibility of the participants (main executors) of the innovation project. Indicative innovation policy means that the university should develop in accordance with civil and public indicators (standards, norms) established by society. Selective innovation policy means development in priority directions, determined by external innovation and industrial policy of the state and the region.

Traditional approach to the formation of innovation policy means that it does not take into account the requirements of the external environment, qualitative changes in the internal environment, the level of development of the university itself. Intuitive approach implies the development of innovation policy by one person on the basis of intuitive feelings. Scientifically grounded innovation policy is a collective social process of improving the activities of universities based on established traditions, best international practices, trends in the development of the university and the country with the obligatory consideration of national peculiarities.

The innovation policy of an entrepreneurial university may include the following main directions:

- educational (organization of the educational process, provision of statutory educational services, development of educational technologies, organization of methodological work, etc.);

- scientific, research and technology (organization of scientific research in priority areas of science and technology, automation and informatization of all spheres of university activities, implementation of design work, development of new equipment and high technology);

- cultural and educational (children's upbringing, education, parental, cultural and educational work with students, organization of social and humanitarian and socially useful activities of students and teachers, patronage of schools, participation in charitable projects, etc.)

- administrative and managerial (making administrative and managerial decisions at different levels of university management: rectorate $\rightarrow$ deans $\rightarrow$ departments $\rightarrow$ executors; councils $\rightarrow$ implementation of council decisions); 
- financial (new forms of use of financial savings; expansion of sources of financial resources, funds; new methods and measures to preserve and increase the financial resources of the university);

- academic-entrepreneurial (patent and licensing activities, technology transfer and dissemination of new knowledge, commercialization of R\&D results, creation of new technologies and startups);

- economic (administrative and economic activities), commercial (obtaining additional income through: commercial use of real estate and material and technical means of the university; the organization on commercial terms related and additional educational and scientific services, professional advice and expertise; provision of premises and equipment for forums, conferences, seminars on lease terms; production and sale of university souvenirs; organization on contractual terms of publishing activities for internal and external customers, etc.), auxiliary and other (by type of university activities);

- sports (organization of sports competitions, leisure time of students and teachers, strengthening health and improving the lives of students and lecturers); - cooperation with the "outer world" (business contacts with customers and consumers of educational and scientific services, commercialized R\&D results, representatives of the state (government), industry (business), presence in the markets of educational and scientific services, participation in competition with other universities and scientific (research) institutes);

- extracurricular activities of the university (organization of various competitions, cultural events, humanitarian and international programs).

Budgetary innovation policy is a policy that is fully financed from the budget of all levels: state, regional, municipal. Extrabudgetary innovation policy is financed at the expense of financial resources of extrabudgetary funds, firms, enterprises, organizations and institutions, population, sponsors, foreign sources. Having its own funding, the university carries out innovative activities at the expense of earned funds (financial resources). Multichannel innovation policy assumes that funding comes from all of the above sources, financial resources (loans) of banks can also be attracted.

By the nature of the implementation of innovation policy can be stable, that is implemented in accordance with the adopted program and plans for innovation, or unstable, that is implemented to the extent of objective and subjective necessity.

Innovation policy can be based on low (average) or high degree of implementation of entrepreneurship in higher education institutions. Budget (state, municipal) higher educational institutions with substantial state support can afford to use only some types of entrepreneurship (marketing, advertising, search for customers of educational and scientific services and potential employers for graduates). For private educational institutions entrepreneurship is the main tool for the implementation of statutory activities.

In practice, it is possible to conduct an external intensive, moderate degree of sustainability of innovation policy, based on multi-channel (multiresource) model of financing and effective statutory entrepreneurial activity. The internal policy should correspond to the external one. Otherwise, the university will not only fail to develop, but may even cease its activities.

It is expected that the results of the implementation of innovation policy of universities can be both internal innovative development of universities and innovative development of the region, local, regional and national economic growth. Innovation in industry (business) can be implemented through the transfer of innovative technologies, the transfer (transplantation) of new industries, the opening of new firms and companies (start-ups), the improvement and innovative transformation of existing industrial facilities and so on. Along with excellence in academic entrepreneurship to commercialize R\&D results, innovative development at the local, regional and national levels is a significant contribution of universities to the social and economic improvement of society.

Any process corresponds to certain relations developing between its participants. Innovation policy is characterized by innovative relations, which must be implemented by the subjects and objects of management.

The subject of managerial relations is an active link, influencing these relations; the object of managerial relations is a passive part of relations, perceives influence and is subjected to it. In this sense, any subject (carrier) of managerial relations is both active and passive in one way or another. The subjects (carriers) of innovative relations of higher education are all members of society, social groups, social structures connected in one way or another with the sphere of education, science and production. They can be individual and associated (collective).

The University can also act as a subject and object of interaction with the external environment at the macro-, meso- and micro-levels (in terms of innovative attitude to the environment and the importance of action, as well as on the spatial scale and the effect of action). From the point of view of macroeconomics, universities themselves, being the institutional links of the formal education system, can also act as subjects of innovative relations. At the same time they act as objects of management. The university can act as an economic entity in the research and production complex, in the regional educational system, in the system of continuing education, entering into both internal (intra-university, intra-institutional, 
intracorporate) and external management relations with the external environment. At the micro level the subjects of innovative actions are heads of universities - structural subdivision responsible for innovation policy. The objects of management are, on the one hand, innovative activity, on the other hand, the entire team of the university. Actually, innovative relations arise between people regarding the formation and implementation of innovations. In this case, the processes associated with the production and recreation of the new (new knowledge, new products or services, new managerial combinations, new social relations) or simply with the introduction of changes to the already known, existing, must not be spontaneous, unconscious, but necessarily consciously put on a scientific basis and have the character of specialization. From this point on, when innovative relations become such that they are constantly reproduced, we can talk about a special type of managerial relations - innovative relations, which are present in any sphere of human life, including higher education and science.

In higher education there are innovative relations of both objective and subjective nature (Figure 2). They are realized through the interests of subjects and objects of higher education.

Objective innovative relations in education are socio-economic in nature, directed by the interests of society and dependent on it. Such relations include the following:

- innovation and economic, including innovative and market (innovative entrepreneurial);

- innovative and pedagogical;

- innovative and managerial, including innovative and organizational;

- innovative and financial;
- innovative operations with property.

Subjective innovative relations include innovation and psychological, and innovation and moral, affecting feelings, emotions and subjective ethical assessments of people. They also include relations of innovative corporate culture.

Innovation and psychological, in particular, is the psychological contour of the relations expressing the psychology of the economic entities and the university. For example: the expectation, patience and continuing trust in the authorities on the part of the scientific and pedagogical body about the equitable distribution of rich in their potential and at the same time limited resources. They are an important part of the sociopsychological relationships that last in education when everything else is disappearing. A teacher, a scientist are those professions in which vocation, talent, giftedness, desire to create and serve mankind are of paramount importance. These professions will be alive as long as human beings are alive.

The relations of innovative corporate culture or innovative-moral relations are such relations between people, which can be evaluated in terms of good and evil (for example, it is honesty, reliability of social relations of economic entities). The innovative corporate-entrepreneurial culture of the university is important (see below). Innovative moral and ethical norms of relationships in educational institutions are also very important, which can act as a protection against abuse and corruption.

All types of innovative relations in education (see Figure 2) are carried out in the system of reproduction of goods and resources, branch, regional and intersectoral relations: between spheres of economy and society, between education and society.

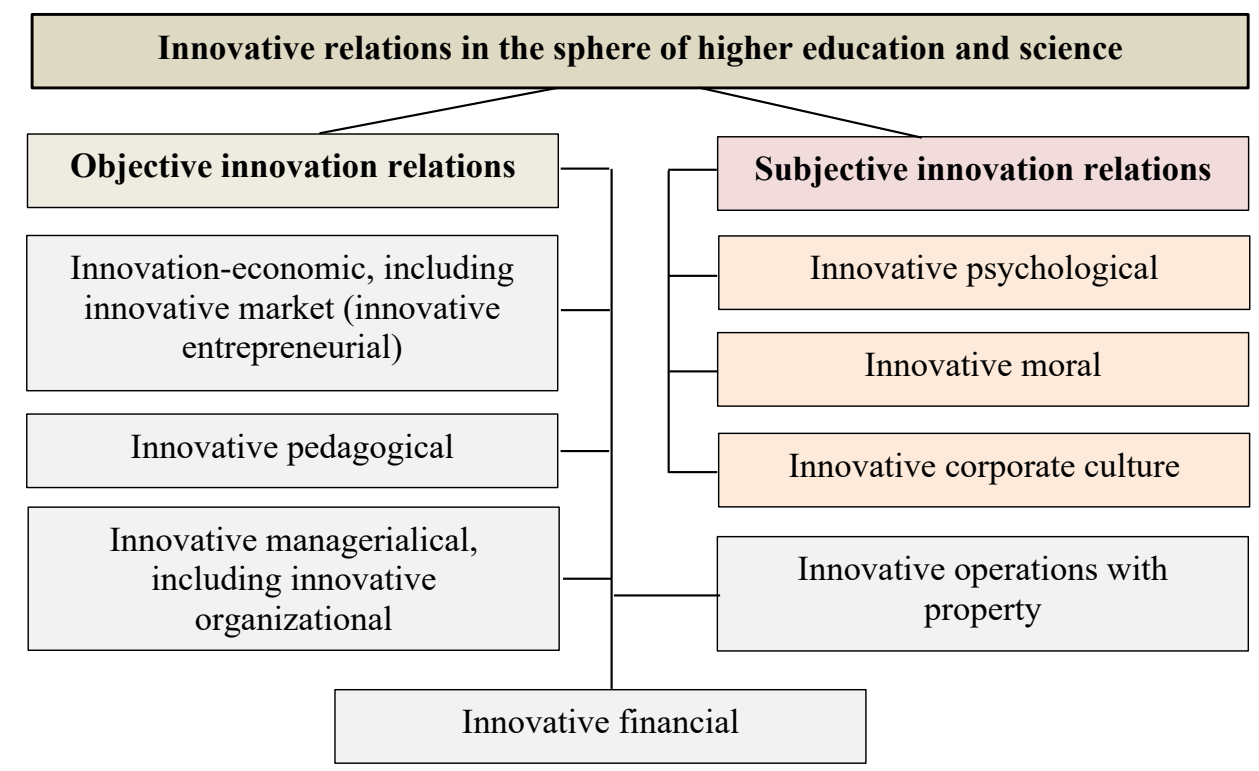

Figure 2. Innovative relations in the sphere of higher education and science 
Changes in innovation and economic relations in higher education, carried out on a systematic scientific basis, accelerate social progress. Other types of innovative relations, especially innovative-financial and innovative-managerial ones, can and should contribute to such progress by synchronizing innovative changes. These types of relations are characteristic both for external and internal innovative policy of higher education institution.

The central issue of innovation policy in higher education and science is how government officials and decision makers in higher education and science should focus on developing competencies (education, training, and skills) in developing and implementing innovation.

Here is a brief look at the typology of internal and external, as well as individual and organizational sources of competence related to innovation in this area.

Identify "three common weaknesses and imbalances in innovation systems in terms of education, training and skills: a) insufficient levels of competencies in the system; b) the time lag between the short-term needs of firms for specific competencies and c) the long time required to develop them, and the imbalance between internal and external sources of competencies in firms" (Borrás \& Edquist, 2015). In addition, they define "competencies as the set of knowledge, skills, and experiences that people and organizations possess. They can be seen as a set of acquired abilities and dispositions to perform a particular activity, often including a specific set of (analytical, physical, etc.) techniques and methods; and based on a certain level of past experience. Consequently, competencies are the result or outcome of a process to which people or organizations are exposed (a pattern of learning and/or a series of new tasks)."

In general, different types of competencies can be distinguished: managerial competencies or skills; scientific, educational, technological, engineering and mathematical competencies; or more general social, economic and communication competencies.

The authors define that "competence formation, for its part, is the actual process of formal or informal development or acquisition of specific competencies by individuals and organizations. It should be noted that we proceed from the perspective of the learning economy ... as an appropriate first step in this topic of competence formation. According to this view, innovation performance in the economy is highly dependent on the learning of organizations and individuals, understood as their continued ability to adapt to and change in relation to a rapidly changing external context based on their competencies and their ability to build on those competencies."

Thus, it is logical to conclude that in the field of higher education and science a) competences are a set of professional knowledge, skills and experience possessed by individuals and universities; b) competence development is a process of formal or informal development, training and acquisition by individuals and universities of specific competences in a given field.

From the perspective of the innovation system, one of the most important aspects is the process by which competencies are created, maintained and developed.

There is a close connection between a university's internal capabilities and its ability to draw on external sources of knowledge. Universities interact with other universities, firms, companies, and other types of organizations in different ways and with different goals in terms of knowledge and skills. There are some forms of external interaction that are critical for two reasons; first, because they are one of the most common forms of external university interaction in innovation systems; and second, because they demonstrate a high level of learning, experience, and/or skill development in ways that universities can potentially benefit from external knowledge sources. Such forms of external interaction are as follows:

a) university-industry relations aimed at developing human resources;

b) university-to-university relationships aimed at advancing science and technology for human needs;

c) leading users of free economic services as key external sources of knowledge for innovation processes;

d) artificial intelligence, based on a human-centered method of computer modeling in which part of the research is outsourced, as well as crowdsourcing, as a new form of collective pooling of knowledge resources in the innovation system.

Consider the essence of internal and external sources of competence for universities (Figure 3).

In many countries there are various types of state activities related to the creation, maintenance and development of competencies, which have a direct and indirect impact on the innovative activities of HEIs, firms and other organizations in the system.

The traditional cornerstones of state activities to support competencies, formation and development of competencies in the innovation system are:

- regulation, organization and financing of education systems (primary, secondary, higher and postgraduate - both public and private);

- support and incentive schemes for vocational training systems.

S. Borrás and C. Edquist identify the following three common types of deficiencies, tensions and imbalances in the innovation system:

- Insufficient level of competence in economics and/or complete loss of competence.

- The time gap between the short-term needs of firms and the long time needed to develop competencies. 
An imbalance between internal and external competencies, leading to excessive isolation from or dependence on external sources.

The first is related to a lack of competencies in the economy. This may be because the economy is unable to create the competencies its firms need for a stable level of innovation, or because there is a complete loss of competencies due to negative migration flows in the country or region. The development of competencies in economics is not only related to the level of academic achievement or training. Competence in economics is also highly dependent on the continuous development of skills and experience in the organization of work. It is now widely recognized that this type of know-how, based on skills and experience, is important for the level of competence in the economy.

As a result, the impact of offshore production activities on the level of competence in the economy has been debated worldwide for many years. The relocation of firms' production activities in recent decades to lower-wage countries is a loss of jobs and competencies in the home country. Skills and experience are based on mid-level employees and managers with practical experience in production organization.

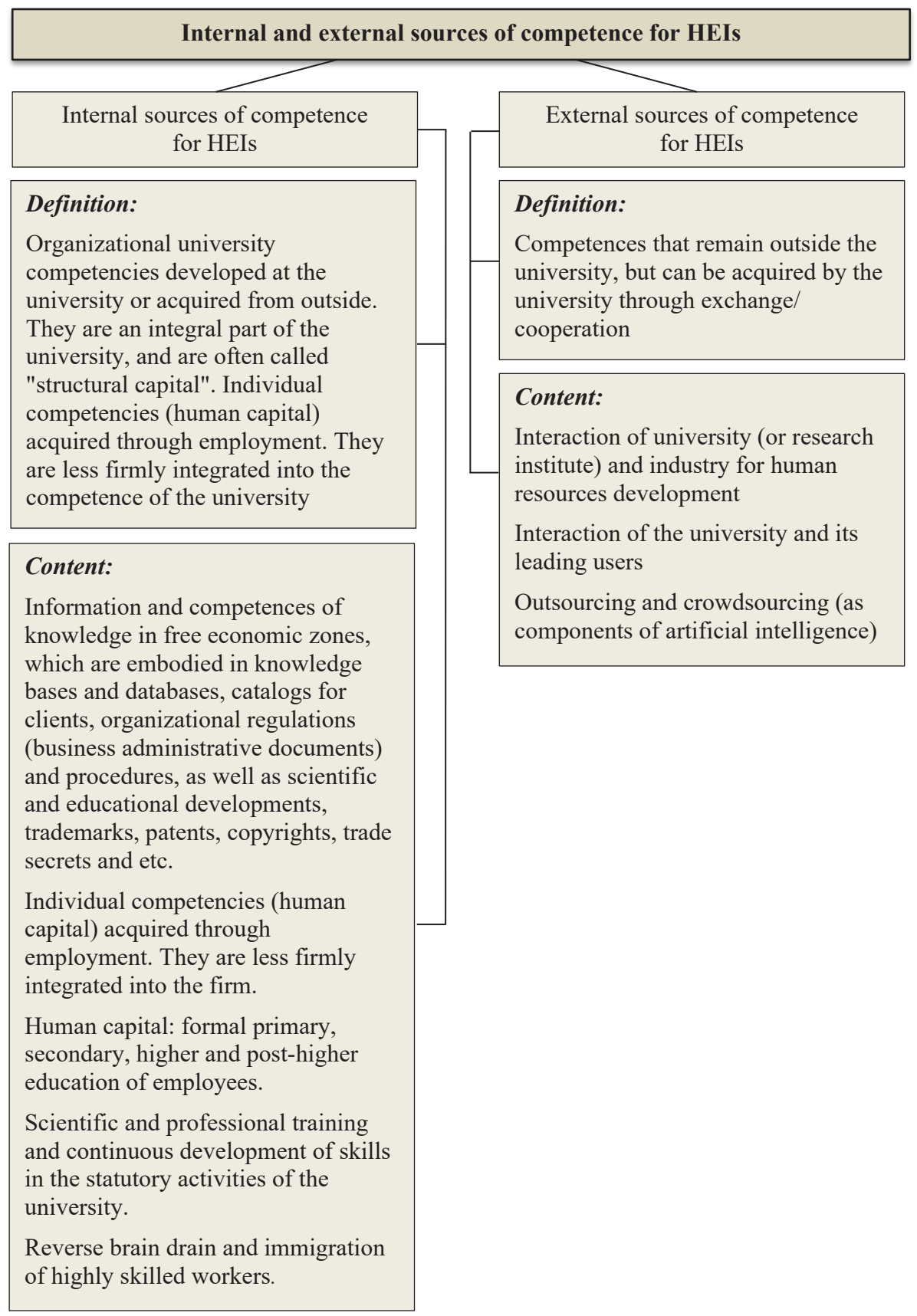

Figure 3. Internal and external sources of competence for HEIs 
Workers involved in product and process innovation require in-depth knowledge of the product and its production process, which cannot be achieved in research laboratories alone. In addition, advanced forms of production depend not only on a significant level of scientific and technical knowledge, but also on skilled and experienced workers, that is, on competence.

The second question concerns the time lag between the needs of firms for specific competencies in the short term and the long time required to develop them.

The third group of potentially problematic issues in the innovation system is the imbalance between internal and external competencies, which leads to either isolation from external competencies or overdependence on them (Borrás \& Edquist, 2015).

It is the innovative policy in the sphere of higher education and science that should help to eliminate this imbalance.

Universities and colleges should develop innovative programs, technologies and methods of advanced training for timely formation and development of necessary competencies for all spheres of social and economic activity of the world community.

\section{Conclusions}

Academic capitalism makes the innovative development of higher education and science real and inevitable. Both theoretical research and practical experimentation, as well as the creation of fundamental knowledge in this area, are needed to better understand the promising directions of such development.

It is innovatics of higher education is designed to combine theoretical research and practical experience to better understand the essence of innovation in the sphere of higher education and science. The study examines some basic issues of innovation policy in the sphere of higher education and science as one of the main components of the state socio-economic policy of social development and is aimed at creating favorable conditions for bringing new ideas created in this sphere to the market.

Considered further development of the theoretical foundations of higher education innovatics, including: activities promoted by higher education innovation; innovative environment of activities promoted by higher education innovation; the main directions of innovation policy of an entrepreneurial university; the main components of the innovation policy of an entrepreneurial university; innovative relations in higher education and science; innovative environment; the importance of having the necessary competencies, their formation and development; internal and external sources of competencies for universities, etc.

The authors suggest that innovation policy in higher education is a link between the policy of research and scientific (scientific and technical) activities; search and dissemination of knowledge; education and training of qualified specialists - on the one hand, and technological development; industrial policy and environmental policy - on the other.

The main directions of innovation policy of entrepreneurial university and innovative relations in the sphere of higher education and science are investigated.

Further research is needed on the formation, improvement and development of competencies necessary for the innovative transformation of higher education and science.

\section{References:}

Altbach, F. (2008). The complex roles of universities in the period of globalization. Higher Education in the World, 3, 5-14. Available at: https://www.researchgate.net/publication/277128834_The_complex_roles_of_ universities in the period of globalization/stats

Baregheh, A., Rowley, J., \& Sambrook, S. (2009). "Towards a multidisciplinary definition of innovation". Management Decision. 47(8): 1323-1339. Available at: https://www.researchgate.net/publication/41104662_ Towards_a_Multidisciplinary_Definition_of_Innovation

Blass, E., \& Hayward, P. (2014). Innovation in higher education; will there be a role for "the academe/university" in 2025? European Journal of Futures Research, 2, 41. DOI: https://doi.org/10.1007/s40309-014-0041-x

Borrás, S., \& Edquist, C. (2015). Education, training and skills in innovation policy. Science and Public Policy, 42(2), 215-227. DOI: https://doi.org/10.1093/scipol/scu043

Bouwer, L. (2015). Capabilities-Driven Innovation Management Framework: Crossing the Innovator's Chasm. Conference: International Association for Management of Technology 2015. Cape Town, South Africa. Available at: https://www.researchgate.net/publication/278016420 Capabilities-Driven_Innovation Management Framework_Crossing the_Innovator's_Chasm

Bouwer, L. (2017). The Innovation Management Theory Evolution Map (Working Paper). Innovation Management Research Institute (IMRI), 7 April. Available at: https://www.academia.edu/32687747/The Innovation_Management_Theory_Evolution_Map

Branch, J., Hørsted, A., \& Nygaard, C. (2018). New Innovations in Teaching and Learning in Higher Education (Learning in Higher Education series). Libri Publishing, $480 \mathrm{p}$.

Brewer, D. J., \& Shirley, M. (2017). Federal Policy to Promote Innovation in US Higher Education, Urban Institute, USA, Washington, DC, September 2017. Available at: https://files.eric.ed.gov/fulltext/ED578896.pdf 
Brewer, D. J., \& Tierney, W. G. (2011). "Barriers to Innovation in US Higher Education". In Reinventing Higher Education: The Promise of Innovation, edited by Ben Wildavsky, Andrew P. Kelly, and Kevin Carey, 11-40. Cambridge, MA: Harvard Education Press.

Cadorin, E., Klofsten, M., Albahari, A., \& Etzkowitz, H. (2019). Science Parks and the Attraction of Talents: Activities and Challenges / Eduardo Cadorin, Magnus Klofsten, Alberto Albahari, Henry Etzkowitz, Triple Helix Journal, September 2019, 1-33. Available at: https://www.researchgate.net/publication/336278817_Science Parks_and_the_Attraction_of_Talents_Activities_and_Challenges

Cai, Y., Ma, J., \& Qiongqiong C. (2020). Higher Education in Innovation Ecosystems Sustainability, 12, 320 p. Available at: https://www.mdpi.com/books/pdfview/book/2956

Chen, J., Viardot, E., \& Brem, A. (2019). Innovation and innovation management. The Routledge Companion To Innovation Management, Routledge, pp. 3-36. Available at: https://www.researchgate.net/ publication/331189067 Innovation and innovation management

Clark, B. R. (2000). Collegial Entrepreneurialism in Proactive Universities: Lessons from Europe. Change: The Magazine of Higher Learning, 32(1), 10-19. Available at: https://www.tandfonline.com/doi/ abs/10.1080/00091380009602704

Clark, B. R. (2004). Sustaining Change in Universities. Continuities in Case Studies and Concepts. The Society for Research into Higher Education \& Open University Press, England, McGraw-Hill, 232 p.

Clark, B. R. (1998). Creating Entrepreneurial Universities: Organizational Pathways of Transformations. Oxford, Pergamon-Elsevier Science, 180 p.

Damanpour, F. (2020). Organizational Innovation: Theory, Research, and Direction. Rutgers University, USA, EdgarOnline Business Collections. Available at: https://www.researchgate.net/publication/342788468_ Organizational_Innovation_Theory_Research_and_Direction

Drucker, P. (2002). "The Discipline of Innovation". Harvard Business Review. August 2002. Available at: https://hbr.org/2002/08/the-discipline-of-innovation

Dzisah, J., \& Etzkowitz, H. (2012). The Age of Knowledge: The Dynamics of Universities, Science and Societies. Leiden-Boston, Brill, $360 \mathrm{p}$.

Edison, H., Ali, N. B., \& Torkar, R. (2014). Towards innovation measurement in the software industry. Journal of Systems and Software, 86(5), 1390-1407. Available at: https://torkar.github.io/pdfs/jss-edisonNT13.pdf

Etzkowitz, H. (2019). Is Silicon Valley a global model or unique anomaly? Industry and Higher Education, 33(2), 83-95. Available at: https://journals.sagepub.com/doi/abs/10.1177/0950422218817734

Etzkowitz, H. (2003). Innovation in Innovation: The Triple Helix of University-Industry-Government Relations. Social Science Information, 42(3), 293-337. Available at: https://www.researchgate.net/publication/249733214 Innovation_in_Innovation_The_Triple_Helix_of_University-Industry-Government_Relations

Etzkowitz, $\bar{H} . \overline{(2008)}$. The Triple Helix: University-Industry-Government Innovation in Action. New York \& London: Routledge, Taylor \& Francis Group, 164 p.

Granstrand, O., \& Holgersson, M. (2020). Innovation ecosystems: A conceptual review and a new definition, Technovation, 90-91, 102098. DOI: https://doi.org/10.1016/j.technovation.2019.102098

Jakovljevic, M. (2018). A model for innovation in higher education. South African Journal of Higher Education, 32(4), 109-131. Available at: https://www.journals.ac.za/index.php/sajhe/article/view/2432

Jessop, B. (2018). On academic capitalism. Critical Policy Studies, 12(1), 104-109. DOI: https://doi.org/ $10.1080 / 19460171.2017 .1403342$

Leslie, L., Oaxaca, R., \& Rhoades, G. (2001). Technology Transfer and Academic Capitalism. In Albert Teich, H., [and others], editors. AAAS Science and Technology Policy Yearbook, part 7, article 23, pp. 261-277.

McCowan, T. (2017). Higher education, unbundling, and the end of the university as we know it. Oxford Review of Education, 43(6), 733-748. July, 2017. DOI: https://doi.org/10.1080/03054985.2017.1343712

Mensch, G. (1979). Stalemate in technology : innovations overcome the depression. Cambridge, Mass.: Ballinger Pub. Co., 241 p.

Mission-Oriented Innovation policies (2020). Welcome to the OECD Mission-Oriented Innovation policies online toolkit. Available at: https://stip.oecd.org/moip/ (accessed November 11, 2021).

Münch, R. (2020). Academic Capitalism. Oxford University Press. Published online: 09 May 2016 \& 30 April 2020. Available at: https://oxfordre.com/politics/view/10.1093/acrefore/9780190228637.001.0001/acrefore9780190228637-e-15 (accessed November 11, 2021).

Otten, S. (2018). Innovative policy development around the world. A NSW Government website, Nov. 1, 2018. Available at: https://www.digital.nsw.gov.au/article/innovative-policy-development-around-world (accessed December 12, 2021).

Rogers, E. M. (2003). Diffusion of innovations (5th ed.). New York: Free Press, 576 p. Available at: https://books.google.com.eg/books?id=9U1K5LjUOwEC\&printsec=frontcover\&hl=ru\#v=onepage\&q\&f=false Romanovskyi, O., \& Romanovska, Yu. (2020). Higher educational innovatics as the newest interdisciplinary directon of higher school and higher education science. Interdisciplinary Studies of Complex Systems, 17(2020), 83-101. Available at: http://iscs-journal.npu.edu.ua/article/view/216975 
Romanovskyi, O., Romanovska, Yu., \& Romanovska, O. (2021). Academic capitalism as a driver of transformational change in the complex system of higher education and science. Baltic Journal of Economic Studies, 7(4), 165-175.DOI: https:/ /doi.org/10.30525/2256-0742/2021-7-4-165-175

Romanovskyi, O. O., \& Romanovska, Yu. Yu. (2019). Innovation in University Education as a Factor of Sustainable Development of Ukraine. Theoretical Approach, Business, economics, sustainability, leadership and innovations, 3, 67-84. Available at: https://www.besli.org/index.php/besli/article/view/28

Schumpeter, J. A. (1934). The Theory of Economic Development: An Inquiry into Profits, Capital, Credits, Interest, and the Business Cycle. Transaction Publishers, Piscataway, $255 \mathrm{p}$.

Schumpeter, J. A. (1976). Capitalism, Socialism and Democracy. Routledge, 437 p.

Serdyukov, P. (2017). Innovation in education: what works, what doesn't, and what to do about it? Journal of Research in Innovative Teaching \& Learning, 10(1), 4-33. Available at: https: //www.emerald.com/insight/ content/doi/10.1108/JRIT-10-2016-0007/full/pdf?title=innovation-in-education-what-works-what-doesntand-what-to-do-about-it

Slaughter, S., \& Leslie, L. (1997). Academic capitalism. Politics, Policies, and the Entrepreneurial University. Baltimore (MA, U.S.A.): The John Hopkins University Press, 276 p.

Somers, P., Davis, C., Fry, J., Jasinski, L., \& Lee, E. (2018). Academic capitalism and the entrepreneurial university: some perspectives from the Americas // Rotero, Joaçoba, vol. 43, no. 1, pp. 21-42, Jan./Äbr. 2018. Available at: https://www.researchgate.net/publication/324458855_Academic_capitalism_and_the_ entrepreneurial_university_some_perspectives_from the Americas

Swanger, D. (2016). Innovation in Higher Education: Can Colleges Really Change? Fulton-Montgomery Community College, NY, 58 p. Available at: https://www.fmcc.edu/about/files/2016/06/Innovation-inHigher-Education.pdf (accessed November 11, 2021).

The Innovation Policy Platform (2013). WORLD BANK \& OECD. Available at: https://www.innovationpolicyplatform.org/www.innovationpolicyplatform.org/frontpage/index.html (accessed December 10, 2021).

The Quest For Innovation (2006). A Global Study of Innovation Management 2006-2016. American Management Association, 86 p. Available at: https://www.amanet.org/assets/1/6/hri_innovation.pdf

Tierney, W. G., \& Lanford, M. (2016). Conceptualizing Innovation in Higher Education. In: Paulsen M. (eds) Higher Education: Handbook of Theory and Research. Higher Education: Handbook of Theory and Research, vol 31. Springer, Cham. DOI: https://doi.org/10.1007/978-3-319-26829-3_1

Viale, R., \& Etzkowitz, H. (2010). The Capitalization of Knowledge. A Triple Helix of University-IndustryGovernment. Edward Elgar Publishing, 368 p. 